\title{
Reformulasi Prosedur Perlindungan Dalam Undang-Undang Penghapusan Kekerasan Dalam Rumah Tangga Yang Tidak Efektif
}

\author{
Aroma Elmina Martha dan Endah Rizki Ekwanto \\ Program Pascasarjana Fakultas Hukum Universitas Islam Indonesia \\ Jln. Cik Di Tiro No. 1, Yogyakarta, 55223 \\ aroma@uii.ac.id; rizkiendah@yahoo.com
}

\begin{abstract}
Law No. 23 of 2004 on the Elimination of Domestic Violence (UU PKDRT) explains that domestic violence (KDRT) is an act against a person - especially a woman - which results in physical, sexual, psychological, and/or neglect of the household including threats to commit acts, coercion or deprivation of liberty unlawfully and within the scope of the household. Thus UU PKDRT is a guarantee offered by the state to prevent, protect, and follow up on perpetrators of domestic violence, but it is not effective. This research aims to examine the ineffectiveness and seek the appropriate reformulation of the articles. This is a juridicalsociological research using the analysis approach on UUKDRT. The results of this study indicate that there are inefficiencies in the articles contained in the UUPKDRT, especially in terms of protection caused by several factors both from the community itself and from law enforcement officials.
\end{abstract}

Keywords: Domestic violence; reformulation of ineffective articles

\begin{abstract}
Abstrak
Undang-Undang No. 23 Tahun 2004 tentang Penghapusan Kekerasan Dalam Rumah Tangga (UU PKDRT) menjelaskan bahwa kekerasan dalam rumah tangga (KDRT) adalah perbuatan terhadap seseorang - terutama perempuan - yang mengakibatkan kesengsaraan fisik, seksual, psikologis, dan/atau pelantaran rumah tangga termasuk ancaman untuk melakukan perbuatan, pemaksaan, atau perampasan kemerdekaan secara melawan hukum dan lingkup rumah tangga. PKDRT ini merupakan jaminan yang diberikan oleh negara untuk mencegah, melindungi, dan menindak lanjuti pelaku KDRT, namun tidak efektif. Penelitian ini bertujuan untuk mengkaji ketidak-efektifan tersebut dan mencari reformulasi pasal yang tepat. Penelitian bersifat yuridis-sosiologis dengan menggunakan metode pendekatan analisaUUKDRT. Hasil dari penelitian ini menyimpulkan bahwa terdapat ketidak-efektifan dalam pasal-pasal yang terkandung dalam UUPKDRT terutama dalam hal perlindungan yang disebabkan oleh beberapa faktor baik dari masyarakat itu sendiri maupun dari aparat penegak hukum.
\end{abstract}

Kata-kata Kunci: KDRT; reformulasi pasal yang dianggap tidak efektif 


\section{Pendahuluan}

Sebagai hukum yang bersifat publik, hukum pidana menemukan arti pentingnya dalam wacana hukum di Indonesia. Bagaimana tidak, di dalam hukum pidana itu terkandung aturan-aturan yang menentukan perbuatanperbuatan yang tidak boleh dilakukan disertai ancaman berupa pidana dan menentukan syarat-syarat pidana dapat dijatuhkan.

Dewasa ini, sedang hangat-hangatnya diperbincangkan terkait Rancangan KUHP yang sementara dikerjakan, hal ini tidak lain untuk memperbaharui beberapa aturan atau pasal-pasal dalam undang-undang karena Indonesia sampai dengan saat ini masih menggunakan KUHP dari Belanda yang dianggap belum sesuai dengan keadaan di Indonesia yang tumbuh dan berkembang dengan berbagai macam hukum adat dan budaya serta nilai moralnya yang lahir ditengah-tengah masyarakat Indonesia. Sehingga dirasa perlu untuk melakukan beberapa aturan.

Terlepas dari peraturan mana saja yang sedang diperbaharui dalam Rancangan KUHP yang sekarang marak diperbincangkan, Undang-Undang No. 23 Tahun 2004 tentang Penghapusan Kekerasan Dalam Rumah Tangga adalah merupakan undang-undang yang dibentuk oleh pemerintah yang telah ada dan diundangkan sejak 2004. Sebelum adanya undang-undang penghapusan Kekerasan Dalam Rumah Tangga ini sebelumnya pemerintah pernah membentuk Undang-Undang Republik Indonesia No. 7 Tahun 1984 tentang Pengesahan Konvensi Mengenai Penghapusan Segala Bentuk Diskriminasi Terhadap Perempuan. Namun adanya undang-undang ini dirasa belum mampu menghadapi permasalahan diskriminasi terhadap perempuan, karena permasalahan diskriminasi terhadap perempuan itu sendiri yang dianggap semakin hari semakin bertambah dan meningkat serta menjadi sangat luas yang tidak hanya terbatas pada perempuan saja baik yang belum atau yang sudah berrumahtangga. Sehingga dibentuklah undang-undang penghapusan Kekerasan Dalam Rumah Tangga ini, dalam undang-undang diatur lebih luas lagi dan mencakup hampir secara keseluruhan. Karena dengan seiring berkembangnya zaman, yang mengalami diskriminasi dan kekerasan tidak hanya perempuan saja, tetapi baik suami, anak, maupun pembantu rumah tangga dapat menjadi sasaran 
atau korban kekerasan. Itulah kenapa undang-undang penghapusan Kekerasan Dalam Rumah Tangga ini ada karena sejatinya kekerasan tidak hanya terbatas pada perempuan saja dan jenis kekerasannya juga tidak hanya meliputi diskriminasi semata, hanya saja perempuan dan anak adalah merupakan sasaran yang rentan mengalami kekerasan.

Sejauh ini, seperti yang kita ketahui bahwa keberadaan Undang-Undang No. 23 Tahun 2004 tentang Penghapusan Kekerasan Dalam Rumah Tangga ini masih eksis digunakan dalam menangani masalah atau kasus kekerasan yang terjadi dalam ruang lingkup keluarga atau rumah tangga. Eksisnya keberadaan undang-undang penghapusan Kekerasan Dalam Rumah Tangga ini karena belum ada undang-undang yang menggantikan. Jika undang-undang ini masih eksis dugunakan sampai dengan saat ini berarti undang-undang ini dirasa cukup mampu dan mencakup keseluruhan permasalahan terkait kekerasan dalam rumah tangga.

Persoalan tidak hanya berhenti sampai disini, maksudnya adalah ketika undang-undang ini masih eksis digunakan tidak serta merta sesuatu yang menjadi keresahan baik untuk masyarakat maupun untuk penulis hilang begitu saja. Keresahan yang penulis dapati adalah ketika sudah ada undang-undang yang dirasa mampu untuk menangani suatu permasalahan harusnya dan harapannya permsalahan itu tidak akan terjadi kembali atau minimal berkurang, tapi sampai dengan saat ini kekerasan terus saja terjadi, inilah keresahan yang menurut penulis adanya kesenjangan antara das solen dan das sein.

Undang-undang penghapusan Kekerasan Dalam Rumah Tangga ini tidak perlu dihilangkan, namun penulis berharap dapat diperbaiki dan direvisi. Karena menurut penulis, adanya beberapa kesenjangan yang menjadikan sebuah keresahan kepada masyarakat ini disebabkan oleh beberapa faktor, baik dari faktor pasal-pasalnya maupun dari faktor proses acara nya dan latar belakang dari pembentukan undang-undang ini. Selain itu, seperti yang kita ketahui lahirnya undang-undang penghapusan Kekerasan Dalam Rumah Tangga ini jelas dipacu oleh masalah yakni masalah kekerasan yang terjadi diruang lingkup rumah tangga sehingga undang-undang penghapusan Kekerasan Dalam Rumah 
Tangga menjadi sebuah solusi untuk mencegah terjadinya kekerasan dalam rumah tangga. Namun tidak serta merta permasalahan dan keresahan terhadap kekerasan berkurang, nyatanya semakin banyak kekerasan terjadi sehingga itu dianggap merupakan masalah baru lagi, berarti keberadaan undang-undang penghapusan Kekerasan Dalam Rumah Tangga ini tidak berjalan dengan baik dan maksimal. Undang-undang penghapusan Kekerasan Dalam Rumah Tangga ini sudah berlaku sejak 2004 sampai dengan 2019 keberadaan undang-undang penghapusan Kekerasan Dalam Rumah Tangga ini sudah berjalan selama 15 tahun. Untuk lebih mempermudah dan memperjelas apa yang penulis jabarkan di atas dan untuk menghindari kekeliruan pemahaman maka sebelum lebih jauh dalam menjelaskan terkait pasal-pasal yang perlu direvisi, penulis akan menjelaskan terlebih dahulu apa itu politikhukum dan sekilas tentang KDRT .

Semakin berkembangnya politik itu sendiri, tidak bisa dipungkiri bahwa ilmu hukum semakin masuk lebih dalam ke ranah perkembangan ilmu politik. Karena sejatinya politik selalu berdampingan dengan ilmu-ilmu sosial lainnya seperti ilmu hukum. Politik sebagai independent variable secara ektrem diberdakan atas politik yang demokratis dan politik yang otoriter. Sedangkan hukum yang merupakan dependent variable dibedakan atas hukum yang responsif dan hukum yang ortodoks.

Indonesia, merupakan negara yang memiliki berbagai macam adat dan budaya sehingga untuk politik hukumnya juga sesuai dengan apa yang tumbuh dan berkembang dalam masyarakat di Indonesia. Contohnya antara Malaysia dan Indonesia, kedua negara ini memang memiliki persamaan dan perbedaan, namun tidak serta merta menyamakan politik hukum negara masing-masing dalam proses pembentukan suatu kebijakan. Persamaannya seperti isu pokok samasama mengatur mengenai KDRT, perbedaannya isu pokok dalam proses pembahasan undang-undang penghapusan Kekerasan Dalam Rumah Tangga di Indonesia mengenai tindak pidana larangan orang melakukan kekerasan dalam rumah tangga. Sedangkan di Malaysia isu pokok pembahasan akta keganasan 
rumah tangga adalah perlu atau tidaknya diatur khususnya bagi orang Islam. ${ }^{1}$ Itulah satu dari sekian banyak perbedaan antara Indonesia dan Malaysia.

Kekerasan dalam rumah tangga atau yang sering disebut dengan KDRT tidak hanya terjadi terhadap perempuan saja, tetapi ada juga kekerasan yang terjadi baik terhadap anak maupun suami. Menurut Pasal 1 UU Nomor 23 Tahun 2004 tentang Penghapusan Kekerasan dalam Rumah Tangga Kekerasan dalam rumah tangga, kekerasan yang dilakukan di dalam rumah tangga baik oleh suami maupun oleh istri. ${ }^{2}$

Kekerasan dalam rumah tangga saat ini menimbulkan banyak dampak yang tidak hanya buruk terhadap keluarga itu sendiri, pun berdampak buruk terhadap moralitas bangsa yang tercermin dari perilaku pelaku kekerasan dalam rumah tangga. Awalnya permasalahan kekerasan dalam rumah tangga ini dianggap merupakan urusan keluarga yang bersifat privat, namun karena kekerasan dalam rumah tangga terus saja terjadi maka persoalan ini harus keluar menjadi urusan publik walaupun keikutsertaan publik terhadap kekerasan dalam rumah tangga ini masih dianggap tabu oleh para korban. Namun mau tidak mau rasanya persoalan ini harus sudah menjadi tanggung jawab publik/negara.

Ada beberapa pasal dalam undang-undang penghapusan Kekerasan Dalam Rumah Tangga yang kiranya diperlukan untuk dilakukan perubahan atau reformulasi. Tidak jalannya secara efektif undang-undang penghapusan Kekerasan Dalam Rumah Tangga ini selama 15 tahun lamanya mengharuskan ada beberapa perubahan yang dilakukan. Seperti yang penulis jelaskan sebelumnya bahwa, ada beberapa pasal yang baiknya dilakukan revisi yakni pasal prosedur perlindungannya. Menurut Satjipto Rahardjo, perlindungan hukum adalah memberikan pengayoman kepada hak asasi manusia yang dirugikan orang lain dan perlindungan tersebut diberikan kepada masyarakat

\footnotetext{
${ }_{1}$ Aroma Elmina Martha, Proses Pembentukan Hukum Kekerasan Terhadap Perempuan di Indonesia dan Malaysia, Aswaja Pressindo, Yogyakarta, 2013, hlm. 116.

2"Definisi dan PEngertian Kekerasan dalam Rumah Tangga", https://www.bangpurba.com/2013/ 04/defenisi-dan-pengertia-kekerasan-dalam.html, diakses tanggal 29 September 2019.
} 
agar mereka dapat menikmati semua hak-hak yang diberikan oleh hukum. ${ }^{3}$ hakhak tersebut termasuk hak untuk melapor ke pihak yang berwajib, yang telah diatur dalam UU bahwa korban atau masyarakat dapat melaporkan suatu kejadian yang membuat masyarakat merasa resah dan terancam, dapat dilaporkan dengan diberikan waktu $1 \times 24$ jam, bahkan $7 \times 24$ jam, tetapi sama sekali hal ini tidak di implementasikan dengan baik hal ini lah yang paling parah, karena harusnya polisi merupak wadah bagi masyarakat yang siap sedia, namun pada kenyataannya juga implementasinya kurang bahkan tidak maksimal. Menurut penulis, ada beberapa kendala yang dialami oleh pihak kepolisian dalam hal tersebut, yakni pertama, mungkin terlalu banyak kasus yang menumpuk, yang kedua, mungkin kasus KDRT dianggap kasus yang masih bisa diselesaikan secara kekeluargaan, dan yang ketiga, pihak kepolisian sudah terlalu banyak menangani laporan dan kasus-kasus yang serupa.

Namun dalam penelitian ini akan di fokuskan pada pasal yang mengatur terkait prosedur perlindungan yakni Pasal 16 sampai 38 yang agaknya tidak efektif dalam implementasinya. Pasal 16 sampai 38 adalah merupakan pasal-pasal yang mengatur terkait proses perlindungan yang diatur dalam UU No. 23 Tahun 2004 tentang Undang-Undang Penghapusan Kekerasan Dalam Rumah Tangga.

\section{Rumusan Masalah}

Berdasarkan latar belakang di atas, maka dapat ditarik beberapa permasalahan, yakni sebagai berikut: Pertama, mengapa pengaturan mengenai prosedur perlindungan dalam Pasal 16 sampai 38 UU Penghapusan Kekerasan Dalam Rumah Tangga tidak efektif? Kedua, bagaimana reformulasi yang tepat mengenai pengaturan pasal prosedur perlindungan dalam UU Penghapusan Kekerasan Dalam Rumah Tangga?

\section{Tujuan Penelitian}

Berdasarkan rumusan permasalahan yang telah dipaparkan di atas, adapun tujuan dari penelitian ini: Pertama, untuk mengetahui mengapa pengaturan

3"Pengertian Perlindungan Hukum Menurut Para Ahli", diakses dalam http://tesishukum.com/ pengertian-perlindungan-hukum-menurut-para-ahli/, diakses tanggal 21 Oktober 2019. 
mengenai prosedur perlindungan dalam Pasal 16 sampai 38 UU Penghapusan Kekerasan Dalam Rumah Tangga tidak efektif? Kedua, untuk mengetahui bagaimana reformulasi yang tepat mengenai pengaturan pasal prosedur perlindungan dalam UU Penghapusan Kekerasan Dalam Rumah Tangga?

\section{Metode Penelitian}

Pendekatan penelitian ini menggunakan pendekatan yuridis-sosiologis. Penelitian ini menggunakan beberapa pendekatan, yakni: pertama, pendekatan kasus (case approach), yaitu dengan melihat dan menelaah beberapa kasus dalam penerapan pasal-pasal yang akan di kritisi. Kedua, pendekatan perundangundangan (statute approach), yaitu dengan menalaah peraturan perundangundangan khusunya beberapa pasal yang akan dikritisi yang berkaitan dengan permasalahan yang sedang dihadapi. Metode pendekatan ini didukung dengan adanya data empiris, yaitu hasi wawancara dengan narasumber. Pengolahan dan penyajian data penelitian ini peneliti peroleh berupa data primer melalui wawancara kepada Hakim, Kepolisian, LSM, dan LBH, sebagai data sekunder sebagai kajian pokok dalam penelitian ini diperoleh dari Pengadilan Negeri Yogyakarta, Pengadilan Negeri Sleman, Polres Sleman, Polda DIY, LSM Rifka Annisa, dan LBH Yogyakarta.

Penelitian ini menggunakan metode deskriptif kualitatif yaitu penulisan yang dilakukan dengan serangkaian penelitian dengan menggunakan pendekatan kualitatif, berupa pengumpulan, analisa, dan perumusan data yang diperoleh dengan sumber baik undang-undang maupun hasil wawancara dengan narasumber. Sehingga mendapatkan data deskriptif yang bisa menjelaskan permasalahan yang diangkan dalam penelitian ini. Kemudian setelahnya dapat ditarik sebuah kesimpulan.

\section{Hasil Penelitian dan Pembahasan}

Harus diakui bahwa lahirnya undang-undang penghapusan Kekerasan Dalam Rumah Tangga ini merupakan terobosan progressif dari sistem hukum pidana, yang seharusnya sudah memiliki kriteria lebih spesifik dari segi ancaman 
hukumannya. Namun, di dalam pelaksanaannya undang-undang ini masih menitiberatkan kepada penghukuman pelaku yang berujung jeruji / hukuman pidana penjara, yang notabene itu adalah khas di dalam KUHP yang selalu membahas pelaku. Setelah di undangkan undang-undang ini, terhitung semenjak itulah kekerasan dalam rumah tangga menjadi urusan publik urusan negara yang notabene mau tidak mau akan ada campur tangan pemerintah. Namun dengan cara yang menitiberatkan kepada penghukuman pelaku yang berujung dengan jeruji / hukuman pidana penjara membuat isteri atau korban menjadi berpikir panjang dalam melanjutlan laporan ke kepolisian, karena dengan beberapa alasan yang sangat krusial yakni, ketergantungan ekonomi, ketergantungan karena selalu bersama, tidak tega, dan masih sayang. Hal ini merupakan salah satu faktor yang menyebabkan beberapa pasal di dalam undang-undang ini tidak jalan, karena seperti pendapat Nindia Kepala Bagian Unit KDRT Polda DIY bahwa aturan itu akan berjalan dengan efektif dan maksimal apabila dilakukan dengan bersama-sama selain dalam undang-undang, aparat penegak hukum, perangkat negara, dan terutama masyarakat itu sendiri harus punya andil masing-masing agar aturan ini berjalan searah dan efektif. Karena dengan korban mencabut laporan menjadi satu penyebab melemahnya undang-undang kekerasan dalam rumah tangga ini sehingga mengalami beberapa kendala dalam penanganan kasus kekerasan dalam rumah tangga. Pertama, laporan yang diajukan oleh korban seringkali ditarik kembali dan tidak ditindak lanjuti, padahal korban tidak menyadari bahwa apa yang dia laporkan tersebut merupakan bagian dari tindak pidana. Kedua, beda pemahaman antar penegak hukum terhadap bentuk bentuk kekerasan dalam rumah tangga tentang mekanisme pemberian perlindungan dan belum semua pihak mendukung upaya perlindungan terhadap korban KDRT.

Tidak berjalan dengan efektifnya beberapa pasal yang penulis jabarkan sebelumnya bukan tanpa sebab, kurang lebih seperti inilah permasalahan yang penulis angkat dan penulis akan mencoba menjabarkan jawaban dari rumusan masalah yang penulis peroleh dari hasil wawancara. Sebelum menjabarkan jawabannya, terlebih dahulu penulis akan meringkasnya dalam bentuk table. 


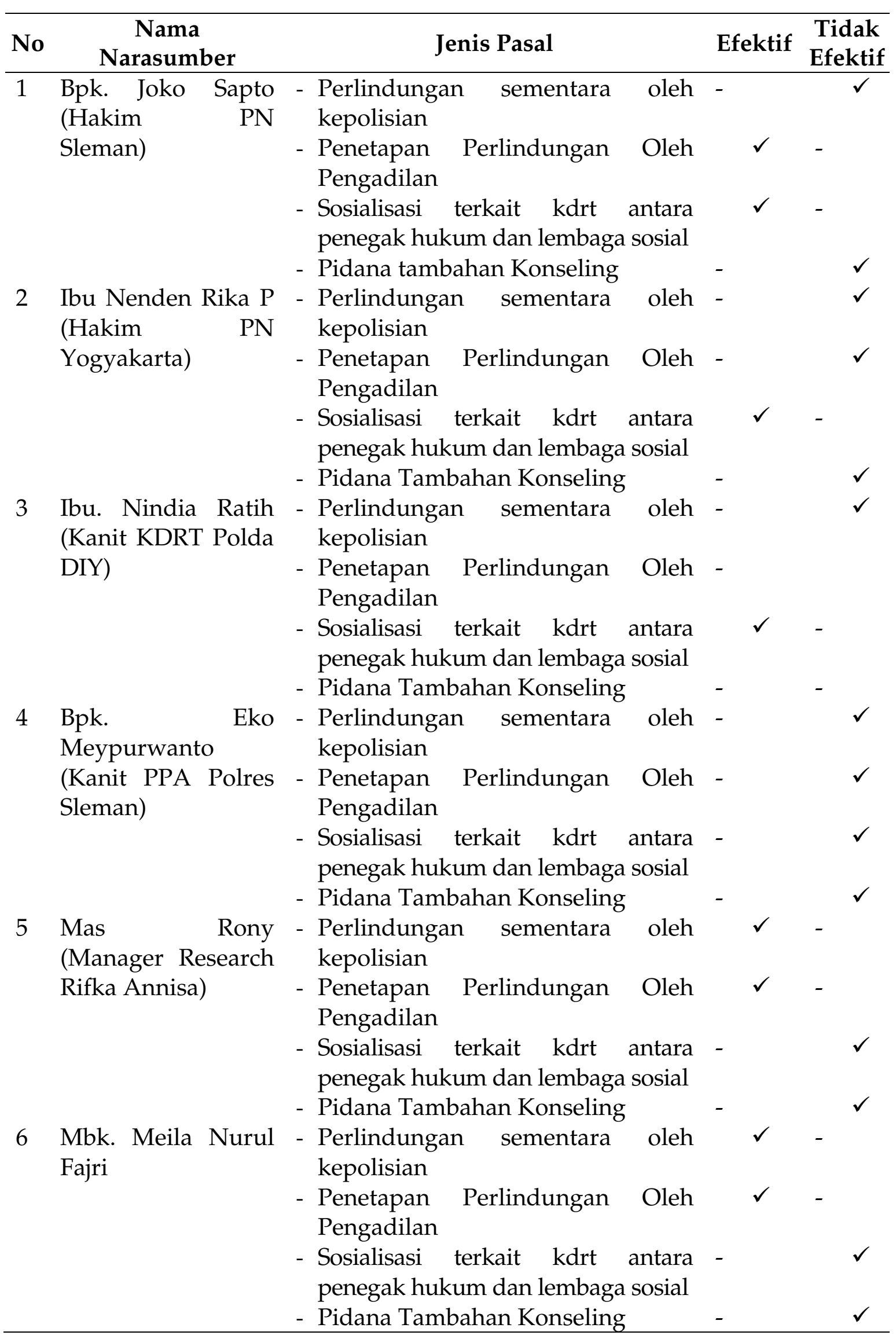


Table di atas hanya sebagian ringkasan yang penulis jabarkan. Permasalahan yang diangkat dalam tugas akhir ini adalah beberapa pasal dalam prosedur perlindungan yang tidak jalan dan tidak efektif. Selain pasal terkait prosedurnya, penulis pun sedikit membahas terkait tanggung jawab pemerintah dan masyarakat yakni tentang sosialisasi kdrt antara aparat penegak hukum dan lembaga sosial. Penulis mendapatkan jawaban terkait permasalahan ini dengan cara wawancara dan hasil wawancara tersebut akan di analisis menggunakan dua teori yakni teori kemanfaatan atau utilitarianisme dan teori efektivitas hukum. Permasalahan pertama, mengapa pasal prosedur perlindungan tidak berjalan efektif. Kedua, bagaimana bentuk reformulasi pasal yang tepat.

Berdasarkan ke enam narasumber yang penulis wawancarai yakni, Kanit KDRT Polda DIY, Kanit PPA Polres Sleman, Hakin PN Sleman, Hakim PN Yogyakarta, LSM Rifka Annisa, dan LBH Yogyakarta. Pendapat ke enam narasumber ini memang bervariasi namun sebagaian besar memang mengakui adanya ketidakefektifitasan dari pasal-pasal tersebut. Alasan dari ke enam nara sumber ini pun bervariasi. Persentasi dari ke enam narasumber $80 \%$ memberikan pendapat setuju bahwa mmang beberapa pasal tersebut kurang efektif. Berikut pendapat para narasumber yang akan disajikan dengan bentuk yang deskripsi :

Pertama, Hakim Pengadilan Negeri Sleman (Bapak Joko Sapto), berpendapat bahwa memang undang-undang penghapusan Kekerasan Dalam Rumah Tangga yang kurang lebih sudah berjalan 15 tahun ini banyak mengalami kendala seperti beberapa pasal dalam prosedur perlindungan sementara $1 \times 24$ jam memang tidak efektif dalam pelaksanaannya karena memang dari pembuat undang-undangnya (DPR) hanya membuat yang baik-baiknya saja tanpa mempertimbangkan hal-hal yang lainnya. Sehingga ketika undang-undang tersebut sudah di undangkan dan siap digunakan maka akan ditemui lah hal-hal yang tidak dipertimbangkan tadi sehingga menjadi sebab dari mandeknya pelaksanaan pasal tersebut. Begitupun terkait dengan penetapan perlindungan dari pengadilan, bahwa efektif tidaknya atau dikabulkan tidaknya suatu permohonan perlindungan tergantung dari pihak kepolisian yang mengajukan permohonan penetapan perlindungan tersebut jadi menurut hakim Pengadilan Negeri Sleman ini penetapan perlindungan dari pengadilan itu tergantung bagaimana progress dari korban saat proses di 
kepolisian. Memang setiap aturan itu akan kita temui fakta bahwa ada beberapa pasal didalamnya yang tidak berjalan dengan baik dan efektif. Begitupun dengan sanksi pidana tambahan yakni konseling, yang bahkan sama sekali tidak berjalan dikarenakan kelemahan terletak pada masalah teknis, dan menurut Hakim Pengadilan Negeri Sleman mandeknya penerapan sanksi pidana tambahan konseling disebabkan oleh tidak adanya biaya yang memadai atau yang dapat memfasilitasi untuk dilakukannya konseling. Sama hal nya dengan Pasal 12 Undang-Undang Penghapusan Kekerasan Dalam Rumah Tangga yakni mengatur tentang kewajiban pemerintah dan masyarakat dalam hal merumuskan kebijakan tentang kekerasan dalam rumah tangga, menyelenggarakan komunikasi, edukasi, informasi serta sosialisasi terkait kekerasan dalam rumah tangga yang dalam pelaksanaannya juga sering mengalami kendala. ${ }^{4}$

Kedua, Hakim Pengadilan Negeri Yogyakarta (Ibu. Nenden Rika P), berpendapat bahwa ada kelemahan kelemahan yang terdapat dalam prosedur perlindungan ini. Kelemahannya adalah pada keamanan korban walapun sudah ada usaha dari pemerintah memberikan perlindungan karena pada kenyataannya rasa keamanan dari korban itu sulit dipulihkan karena menyatu dengan rasa trauma dan rasa takut, pun dengan persoalan yang mencabut laporan ketika korban merasa laporan ini sudah cukup membuat suaminya shock dan jera. Alasan lain pun adalah merasa menyesal, tidak tega, dan ada rasa ketergantungan. Sebenarnya hal seperti inilah yang mengganggu kelancaran dari proses perlindungan itu sendiri, begitupun halnya dengan penetapan perlindungan dari pengadilan. Namun, memang sudah seperti itu jalannya karena dari kami aparat penegak hukum juga menginginkan ada kedamaian dan kerukunan yang tercipta dari kedua pihak. Kemudian yang berhak mengeluarkan surat penetapan perlindungan itu adalah ketua pengadilan namun apabila dari pihak kepolisian tidak mengajukan permohonan maka dari pengadilan juga tidak akan mengeluarkan apapun. Karena kami hanya berfungsi sebagai fasilitator yakni memfasilitas manakala dibutuhkan surat penetapan perlindungan, bukan

${ }^{4}$ Hasil wawancara dengan Hakim Pengadilan Negeri Sleman (Joko Sapto), tanggal 3 Februari 2020, Pukul 09.25 WIB. 
berarti kami yang akan mengawali dan memberikan perlindungan untuk korban. Kemudian terkait dengan sosialisasi, bahwa pendapat Hakim Pengadilan Negeri Yogyakarta ini bahwa sosialisasi terkait kekerasan dalam rumah tangga ini sebenarnya jalan hanya saja yang di sosialisasikan hanya kekerasan secara umum. Menurut Hakim Pengadilan Negeri Yogyakarta ini mengakui bahwa sanksi pidana tambahan yakni konseling tidak berjalan dengan efektif. Secara pribadi juga saya tidak pernah menjatuhi hukum sanksi pidana tambahan yakni konseling kepada pelaku karena saya selalu mengedepankan perdamaian antara kedua pihak apalagi ketika korban memperlihatkan kondisi dan keadaan yang baik-baik saja dan sudah memaafkan serta menerima kembali keberadaan suaminya. Tanpa mengesampingkan apa yang menjadi tuntutan jaksa penuntut umum, namun memang secara pribadi tidak pernah menjatuhkan pidana tambahan konseling, saya rasa begitupun yang dilakukan oleh hakim lainnya. ${ }^{5}$

Ketiga, Kanit KDRT Polda DIY (Nindia Ratih), berpendapat bahwa perlindumgan sementara 1 x 24 jam yang menjadi kewajiban polisi yang harus diberikan kepada korban itu memang tidak sepenuhnya efektif dalam pelaksanaannya, karena maksud dari 1 × 24 jam berarti semua anggota yang ada di dalam unit ini harus siap siaga atau sigap di kantor dan dalam memberikan perlindungan yang dimaksud. Namun, saya rasa kita sudah memiliki kerja sama dengan lsm sehingga korban-korban tersebut langsung mendapatkan perlindungan baik dari aspek pembinaan, maupun aspek trauma healing. Memang seharusnya melewati kepolisian di unit Perlindungan Anak dan Perempuan (PPA) atau dari unit Kekerasan Dalam Rumah Tangga (KDRT) tetapi kami semua didalam sini perempuan semua sehingga tidak bisa untuk maksimal selama 1 x 24 jam. Jadi, perlindungan sementara ini kalau dikatakan efektif tetapi tidak efektif, dikatakan tidak efektif tapi ada lembaga atau shelter yang sudah menangani begitupun dengan penetapan perlindungan dari pengadilan, selama pengajuan perlindungan sementara di pihak kepolisian mengalami kendala maka tidak akan sampai pada tahap pengajuan permohonan penetapan perlindungan oleh pengadilan. Kalau untuk sosialisasi memang sampai dengan sekarang dari

${ }^{5}$ Hasil wawancara dengan Hakim Pengadilan Negeri Yogyakarta (Nenden Rika P), tanggal 4 Februari 2020, Pukul 11.01 WIB. 
unit Kekerasan Dalam Rumah Tangga ini sering mendapatkan undangan untuk menghadiri sosialisasi jadi sebenarnya sosialisasi ini, tetapi mungkin masyarakat yang enggan menghadiri. Karena memang para undangan untuk sosialisasi ini hanya sebatas ibu-ibu PKK saja. Sehingga dijaminnya sampai ke telinga masyarakat awam itu kecil dan mungkin salah satu faktornya sosialisasi ini tidak merata karena keinginan dari masyarakat itu juga kecil untuk mengikuti sosialisasi-sosialisasi. Seharusnya andil masyarakat itu juga diperlukan untuk ke efektivitas an suatu pasal, karena bisa saja tidak efektif nya suatu aturan karena tidak ada kerja sama dari masyarakat yang jelas-jelas menduduki posisi sebagai subjek hukum yang akan dilindungi dari kejahatan termasuk kejahatan kekerasan dalam rumah tangga ini. ${ }^{6}$

Keempat, Kanit PPA (Perlindungan Perempuan dan Anak) Polres Sleman (Eko Meypurwanto). Narasumber berpendapat bahwa, tidak jalannya perlindungan sementara $1 \times 24$ jam karena terhalang dengan tenaga kerja yang notabene semua adalah perempuan dan tidak mungkin untuk kita biarkan bertahan dikantor selama $1 \times 24$ jam. Memang di pasal prosedur perlindungan, bahwa perlindungan sementara itu menjadi tanggung jawab dari pihak kepolisian terutama uni PPA, namun karena semua anggota adalah yang pertama perempuan semua, yang kedua mereka juga memiliki keluarga sehingga rasanya tidak mungkin untuk diberikan tugas seberat itu. Diakui dengan kendala sepert membuat kami tidak maksimal, maka dari itu kami membuat kerja sama dengan lembaga-lembaga sosial atau shelter untuk menampung korban-korban kekerasan dalam rumah tangga ini. Sehingga ketika korban datang dan meminta perlindungan maka akan kita tanyakan masalah apa yang akan dilaporkan, dan perlindungan seperti apa yang korban inginkan. Disinilah kami menyerahkan korban ke lembaga-lembaga sosial atau shelter aman, namun selama 14 hari itu di shelter akan diajarkan keterampilan baik di ajarkan menjahit, memasak, atau pergi ke salon. Tetapi memang di lembaga ini juga ada kendala karena korban hanya diberi waktu 14 hari dari pertama korban masuk, sedangkan 14 hari ini waktu

${ }^{6}$ Hasil Wawancara dengan Kanit Kekerasan Dalam Rumah Tangga (Nindia Ratih) Polda DIY, tanggal 29 Januari 2020, Pukul 14.05 WIB. 
yang singkat siapa yang bisa jamin bahwa korban ini apakah ketakutannya sudah hilang atau kesehatan psikis nya sudah pulih. Memang perlindungan sementara 1 x 24 jam ini sudah menjadi kewajiban kami tapi harus bagaimana lagi, pelaksanaannya tidak bisa seperti apa yang diperintahkan oleh undang-undang. Penetapan perlindungan dari pengadilan itu juga tidak efektif karena pengadilan berada di posisi sebagai fasilitator dan bukan untuk melindungi dalam arti mengikuti seluruh prosedur perlindungan itupun jika ada surat permohonan dari kepolisian namun apabila tidak ada, pengadilan tidak akan mengeluarkan surat penetapan apapun. Selain itu, yang menjadi kendala dari pelaksanaan perlindungan sementara adalah rasa takut korban terhadap polisi menjadi sebab tidak beraninya korban melapor ke polisi. Ketakutannya itu adalah korban telah berpikir lebih dahulu bahwa akan dimintakan uang oleh polisi. Terkait sosialisasi dari kekerasan dalam rumah tangga ini, memang menjadi tanggung jawab dari pemerintah dan masyarakat. Namun tidak juga berjalan dengan efektif dikarenakan kerja sama antara aparat penegak hukum dan lembaga sosial hanya di atas permukaan saja dan tidak merata sampai ke lapisan-lapisan terbawah dalam arti masyarakat yang sangat awam dengan hukum. Kemudian memang untuk sanksi pidana tambahan konseling memang tidak pernah jalan karena aparat penegak hukum itu masih melihat apa yang menjadi keinginan korban, jika korban ingin damai dan korban sudah merasa cukup mampu menerima suaminya kembali kedalam rumah korban akan meminta secara kekeluargaan saja, jadi dengan otomatis sanksi pidana konseling ini tidak akan berjalan dengan baik dan efektif. ${ }^{7}$

Kelima, Manager Research Rifka Annisa (Rony) berpendapat bahwa proses perlindungan sementara 1 × 24 jam dan penetapan perlindungan dari Pengadilan berjalan sesuai dengan apa yang diatur dalam pasal prosedur perlindungan. Akan menemui kendala yang berasal dari aspek dan metodenya. Berbeda pendapat untuk yang sosialisasi KDRT, narasumber ini beranggapan bahwa malah sosialisasi bukan hanya tidak efektif saja tetapi juga tidak jalan, karena itu juga yang menjadi kritikan untuk pemerintah. Kenapa, karena pemerintah setiap

${ }^{7}$ Hasil wawancara dengan Kanit Perlindungan Perempuan dan Anak (Eko Meypurwanto), tanggal 24 Januari 2020, Pukul 10.35 WIB. 
memberikan sosialisasi hanya membahas secara umum yaitu apa itu KDRT, bagaimana jenis KDRT, apa dampak dari KDRT. Tetapi tidak menjelaskan apa yang sudah dilakukan oleh pemerintah, apa hasil yang telah di usahakan oleh pemerintah sehingga yang sosialisasi ini menjadi hal yang membosankan bagi masyarakat, dan akhirnya menganggap sosialisasi ini tidak penting. Akhirnya apa akibat yang diperoleh yakni terjadi lagi dan lagi kekerasan dalam rumah tangga. Sanksi pidana tambahan atau konseling memang sampai dengan saat ini tidak pernah diterapkan sehingga paradigma korban selalu beranggapan bahwa setiap masalah yang dilaporkan melalui hukum pidana akan berujung dengan hukuman penjara, itulah mengapa banyak yang memilih untuk menyelesaikannya lewat pengadilan agama atau dengan perceraian. ${ }^{8}$

Keenam, Staff bagian KDRT LBH Yogyakarta (Meila Nurul Fajriah) berpendapat bahwa perlindungan sementara dan penetapan perlindungan dari pengadilan sedikitnya sudah efektif karena untuk meminta perlindungan itu adalah merupakan hak dari korban, sehingga dari pihak penegak hukum juga hanya menunggu ketika korban datang dan meminta perlindungan maka kepolisian sigap dalam hal memberikan perlindungan sementara. Terkait sosialisasi dan pemberian sanksi pidana tambahan yakni konseling masih memiliki kendala dalam melaksanakannya, sebenarnya kendalanya adalah di ketersediaan negara memfasilitasi atau mendanai baik untuk sosialisasi apalagi untuk konseling. Dalam hal pemberian sanksi pidana tambahan ini berarti negara harus menyediakan konselor dan harus mendanai, tapi sampai dengan sekarang tidak ada sehingga jelas saja mungkin hakim tidak ada keinginan menjatuhkan sanksi pidana tambahan karena negara sendiri tidak memfasilitasi. ${ }^{9}$

Berdasarkan uraian hasil wawancara diatas bahwa kendala tidak efektifnya suatu pasal dalam undang-undang penghapusan Kekerasan Dalam Rumah Tangga selain karena terkendala dengan kurangnya tenaga pelaksana, korban atau masyarakat itu sendiri pun berpengaruh dari tidak jalannya suatu peraturan

${ }^{8}$ Hasil wawancara dengan Manager Research LSM Rifka Annisa (Rony), tanggal 23 Januari 2020, Pukul 09.19 WIB.

${ }^{9}$ Hasil wawancara dengan Staff bagian KDRT LBH Yogyakarta (Meila Nurul Fajri), tanggal 27 Januari 2020, Pukul 14.15 WIB. 
tersebut. Karena seperti yang di katakan oleh Kanit KDRT Polda DIY dapat efektifnya suatu pearturan apabila ada kerjasama yang baik antara penegak hukum sebagai pelaksana dan masyarakat.

Keberadaan undang-undang KDRT memang wujud dari perlindungan negara kepada masyarakat. Namun seperti yang dikatakan oleh Hakim Pengadilan Negeri Sleman bahwa pembuat undang-undang yakni DPR hanya melihat baiknya saja, tidak mengkorelasikan dengan hal-hal yang lainnya, sehingga ketika undangundang ini dijalankan ditemui lah gesekan-gesekan atau kendala di dalam pelaksanannya. Selama kurang lebih 15 tahun undang-undang ini ada, memang bukan tidak jalan sama sekali. Undang-undang ini pun berjalan namun hanya sebatas laporan yang kemudian dicabut karena KDRT masih diyakini sebagai delik aduan yang sewaktu-waktu dapat dicabut laporannya oleh pelapor, kemudian kalau pun harus sampai proses hanya sebatas memberikan hukum pidana penjara dan mengesampingkan sanksi pidana tambahan yang menurut Manager Research dari LSM Rifka Annisa bahwa penerapan sanksi pidana tambahan konseling inu sangat dibutuhkan untuk memberikan bimbingan kepada korban dan untuk menghindari terjadinya dendam. Tetapi dari segi kacamata hakim, justru pemberian sanski hukuman pidana penjara itu lebih membuat pelaku jera dan sadar.

Prosedur perlindungan sementara $1 \times 24$ jam juga disayangkan oleh pihak kepolisian itu sendiri, kenapa mereka tidak bisa maksimal dalam melakukan tugas dn tanggung jawab. Namun agaknya itu sudah menjadi hal yang biasa karena sampai dengan saat ini belum ada perubahan apapun yang dilakukan baik oleh pembuat undang-undang maupun oleh aparat penegak hukum itu sendiri. Perlindungan sementara memang bukan hanya menjadi kewajiban dari kepolisian, karena dari pihak kepolisian melakukan kerja sama dengan lembagalembaga masyarakat lainnya sehingga korban dapat diesarhkan ke lembaga tersebut. Namun sebenarnya menurut pendapat penulis hal ini sangat serius sehingga keberadaan lembaga masyarakat sebagai tempat menampung korban pun tidak cukup. Karena masyarakat lebih familier dengan polisi dan kepolisian. Ketika mereka mengalami tindakan kekerasan maka tempat yang pertama kali akan dikunjungi adalah kepolisian. Lalu bagaimana jika kekerasan ini terjadi di waktu malam yang larut apakah dengan alasan beberapa narasumber yang 
mengatakan bahwa karena anggotanya perempuan semua maka kami tidak bisa 1 x 24 jam, apakah itu alasan untuk tidak berjalannnya dengan baik dan efektif prosedur perlindungan ini. Menurut penulis itu bukanlah sebuah alasan yang menyebabkan sebuah aturan tidak dijalankan baik dan semestinya. Kemudian apakah ketika dilimpahkan ke shelter atau lembaga yang dimaksud akan memberikan rasa aman sepenuhnya untuk korban, belum tentu. Karena kembali lagi, masyarakat sangat akrab dengan keadaan polisi yang dimana mereka sadar dan selalu tahu kalau polisi itu selalu memberi perlindungan dan keamanan.

Tidak berjalan dengan baik dan efektifnya suatu menyebabkan tidak efektif pula undang-undang ini. Memang perlu diketahui bahwa tidak berjalannya sebuah peraturan itu tidak serta merta kesalahan dari pada undang-undang itu. Namun, rasanya jika redaksi didalam sebuah undang-undang hanya selalu memberikan penekanan kepada pelaku dengan memberikannya sanksi, menurut penulis itu tidak lah adil. Hasil wawancara dengan pihak kepolisian ini membuktikan bahwa kesadaran hukum para aparat penegak hukum juga perlu ditajamkan dan dihidupkan kembali dengan cara membuat redaksi pada isi sebuah peraturan harus ada penekanan kepada aparat penegak hukum yang jika tidak melakukan tanggung jawab seperti apa yang diperintahkan undang-undang, maka harusnya ada sanksi disitu. Tujuannya untuk apa, tujuannya sama seperti dengan memberikan sanski kepada pelaku agar jera. Bedanya untuk aparat penegak sebagai perintah yang apabila tidak dijalankan dengan baik berisi teguran dan sanksi didalamnya.

Hasil wawancara ini dapat menggambarkan bahwa peraturan di undangundang penghapusan Kekerasan Dalam Rumah Tangga sebagian besar tidak sesuai dengan kenyataan yang seharunya. Ketidak sesuaian atau ketidakefektifitasan suatu aturan memang bukan hal yang baru di dalam perkembangan peraturan perundang-undangan di Indonesia.

\section{Reformulasi Pasal yang Tepat Mengenai Pengaturan Pasal Prosedur Perlindungan dalam Undang Undang Penghapusan Kekerasan Dalam Rumah Tangga}

Permasalahan kedua yang dibahas dalam penelitian ini adalah mengenai bentuk reformulasi pasal seperti apa yang tepat mengenai pengaturan pasal 
prosedur perlindungan agar dengan harapan rekomendasi bentuk reformulasi ini dapat membantu agar undang-undang ini berjalan dengan efektif.

Berdasarkan hasil dari wawancara dengan beberapa narasumber, penulis mendapatkan jawaban yakni apabila para narasumber ini berkesempatan menjadi pembuat undang-undang maka akan dimasukan bentuk rekomendasi pasal yang diharapkan dapat membantu pasal-pasal dalam undang-undang penghapusan Kekerasan Dalam Rumah Tangga efektif dalam implementasinya. Berikut bentuk rekomendasi reformulasi pasal-pasal tersebut :

Pertama, ada baiknya apabila ada penekanan terhadap aparat penegak hukum khususnya kepada hakim untuk menerapkan sanksi pidana tambahan yaitu konseling agar penyelesaian dan perlindungan yang dimaksud dalam undang-undang penghapusan Kekerasan Dalam Rumah Tangga bukan hanya menitiberatkan kepada korban saja, tetapi ada upaya pemulihan terhadap pelaku juga.

Kedua, Memasukan pasal terkait budaya dalam proses penegakan hukum terkait kasus kekerasan dalam rumah tangga (KDRT). Karena sejatinya Budaya merupakan salah satu faktor terjadinya kekerasan dalam rumah tangga (KDRT). Mengapa karena masih ada masyarakat yang kental dengan adat dan budaya daerah masing-masing sehingga sesuatu yang dalam undang-undang dianggap sebuah kejahatan, bisa saja dalam budaya mereka menjadi hal yang lumrah. Maksud dari budaya penegakan hukum dalam kekerasan rumah dalam rumah tangga adalah penegak hukum sendiri masih kental dengan budaya serta kebiasaan-kebiasaan. Seperti kepolisian masih menganggap bahwa kekerasan dalam rumah bukan sebuah kejahatan sehingga berjalannya proses sepenuhnya diberikan kepada korban untuk meneruskan atau mencabut. Pemikiran seperti ini sudah menjadi budaya dan kebiasaan yang turun temurun. Sehingga itu perlu dibuatkan aturan meski tidak khusus namun ada pasal yang mengaturnya, karena terkadang penegak hukum itu sendiri masih tidak bisa lepas dari budaya.

Ketiga, memasukan pasal terkait dengan metode perlindungan sementara, dengan cara mengharuskan atau memberikan tanggung jawab kepada satu lembaga khusus untuk menangani selain korban, tetapi juga untuk pelaku. Lembaga dengan anggota yang selaras untuk menangani baik korban maupun pelaku. 
Keempat, memasukan pasal terkait keharusan pemerintah dan lembaga untuk lebih aktif dalam melakukan tanggung jawab nya yakni dalam hal mengadakan kerjasama untuk sosialisasi, memberikan informasi, dan edukasi terkait kekerasan dalam rumah tangga. Maksudnya adalah, harus ada beberapa pasal yang dibuat khusus baik untuk penegak hukum maupun LSM yang berisi peraturan yang tegas yang apabila penegak hukum, LSM, dan tenaga sosial lainnya tidak mengikuti maka akan ada teguran didalam pasal tersebut. Jadi intinya, dalam undang-undang penghapusan Kekerasan Dalam Rumah Tangga bukan hanya ditujukan perlindungannya kepada korban semata, tetapi juga pada pelaku, sama halnya untuk aparat penegak hukum, LSM, dan tenaga sosial lainnya yang telah diatur untuk melaksanakan kewajiban.

Kelima, ada baiknya memasukan pasal mengenai pengaturan alokasi dana untuk memfasilitasi konseling, karena dari pihak pengadilan terutama hakim sendiri kebingungan untuk menerapkan sanksi pidana ini akan diserahkan kepada siapa, siapa yang akan memfasilitasi konselor untuk konseling.

Poin-poin diatas adalah merupakan saran atau bentuk rekomendasi reformulasi pasal yang dianggap tepat untuk pasal-pasal yang belum efektif dalam pelaksanaannya. Dari saran-saran para narasumber ini menggambarkan bahwa kekurangan biaya ternyata menjadi salah satu hal yang sangat krusial sebagai salah satu penyebabnya tidak jalannya sebuah aturan dalam undangundang. Mengapa penulis katakan krusial, karena rekomendasi pasal yang mengatur lembaga khusus untuk menangani pelaku juga pada hakikatnya membutuhkan biaya. Sehingga perlu adanya memasukan aturan alokasi dana terkait hal-hal yang sangat penting seperti lembaga khusus tersebut dan juga sanksi pidana tambahan yang harus menyediakan konselor khusus.

\section{Penutup}

Kesimpulan yang dapat ditarik dari hasil uraian di atas adalah benar adanya beberapa pasal dalam undang-undang penghapusan Kekerasan Dalam Rumah Tangga yang disebabkan oleh beberapa faktor. Faktor secara umum yang menyebabkan tidak efektifnya undang-undang penghapusan Kekerasan Dalam 
Rumah Tangga ini adalah baik dari masyarakatnya maupun dari aparat penegak hukum. Sehingga saran dari penulis adalah perlu dilakukan reformulasi terhadap peraturan khususnya pasal-pasal dalam prosedur perlindungan Pasal 16 tentang perlindungan sementara. Bentuk reformulasinya adalah dengan dihapuskan pasal-pasal prosedur perlindungan tersebut dan menggunakan KUHAP dan KUHP saja dan berjalan dengan lancar.

\section{Daftar Pustaka}

\section{Buku}

Budiardjo, Miriam, Dasar-Dasar Ilmu Politik, Gramedia Pustaka Utama, Jakarta, 2008.

M.D., Moh. Mahfud, Politik Hukum Di Indonesia, RajaGrafindo Persada, Jakarta, 2009.

Martha, Aroma Elmina, Perempuan \& Kekerasan Dalam Rumah Tangga Di Indonesia dan Malaysia, FH UII PRES, Yogyakarta, 2012.

Proses Pembentukan Hukum Kekerasan Terhadap Perempuan Di Indonesia dan Malaysia, Aswaja Pressindo, Yogyakarta, 2013.

Sulaiman, King Faisal, Politik Hukum Indonesia, Thafa Media, Yogyakarta, 2017.

Wahyono, Padmo, Indonesia Negara Berdasarkan Atas Hukum, Ghalia Indonesia, Jakarta, 1986.

\section{Internet}

"Definisi dan PEngertian Kekerasan dalam Rumah Tangga", https:/ / www.bangpurba.com/2013/04/defenisi-dan-pengertiakekerasan-dalam.html, diakses tanggal 29 September 2019.

M. Hariyanto, “Strafbaar feit, Perbuatan Pidana, Tindak Pidana, Perkara Pidana”, https:/ / blogmhariyanto.blogspot.com/2009/07/strafbaar-feit-menurutbambang-poernomo.html, diakses tanggal 21 Oktober 2019.

"Pengertian Perlindungan Hukum Menurut Para Ahli", http:/ / tesishukum.com/pengertian-perlindungan-hukum-menurut-paraahli/, diakses tanggal 21 Oktober 2019.

\section{Lain-lain}

Hasil wawancara dengan Hakim Pengadilan Negeri Sleman (Joko Sapto), Tanggal 3 Februari 2020, Pukul 09.25 WIB

Hasil wawancara dengan Hakim Pengadilan Negeri Yogyakarta (Nenden Rika P), Tanggal 4 Februari 2020, Pukul 11.01 WIB

Hasil Wawancara dengan Kanit Kekerasan Dalam Rumah Tangga (Nindia Ratih) Polda DIY, Tanggal 29 Januari 2020, Pukul 14.05 WIB 
Hasil wawancara dengan Kanit Perlindungan Perempuan dan Anak (Eko Meypurwanto), Tanggal 24 Januari 2020, Pukul 10.35 WIB

Hasil wawancara dengan Manager Research LSM Rifka Annisa (Rony), Tanggal 23 Januari 2020, Pukul 09.19 WIB

Hasil wawancara dengan Staff bagian KDRT LBH Yogyakarta (Meila Nurul Fajri), Tanggal 27 Januari 2020, Pukul 14.15 WIB

Hasil Wawancara dengan Kanit PPA Polres Sleman, Tanggal 24 Januari 2020, pukul 10.35 WIB 